Zbynek POLESNY ${ }^{1}$

Vladimir VERNER ${ }^{2}$

Martina VLKOVA ${ }^{1}$

Jan BANOUT ${ }^{3}$

Bohdan LOJKA ${ }^{1}$

Pavel VALICEK ${ }^{1}$

Jana MAZANCOVA ${ }^{3}$

${ }^{1}$ Czech University of Life Sciences Prague Department of Crop Science

and Agroforestry

Faculty of Tropical AgriSciences

129 Kamycka street

16521 Prague 6 - Suchdol

Czech Republic

${ }^{2}$ Czech University of Life Sciences Prague Department of Economics

and Development

Faculty of Tropical AgriSciences

129 Kamycka street

16521 Prague 6 - Suchdol

Czech Republic

${ }^{3}$ Czech University of Life Sciences Prague Department of Sustainable Technologies Faculty of Tropical AgriSciences

129 Kamycka street

16521 Prague 6 - Suchdol

Czech Republic

\section{Non-timber forest products utilization in Phong Dien Nature Reserve, Vietnam: Who collects, who consumes, who sells?}

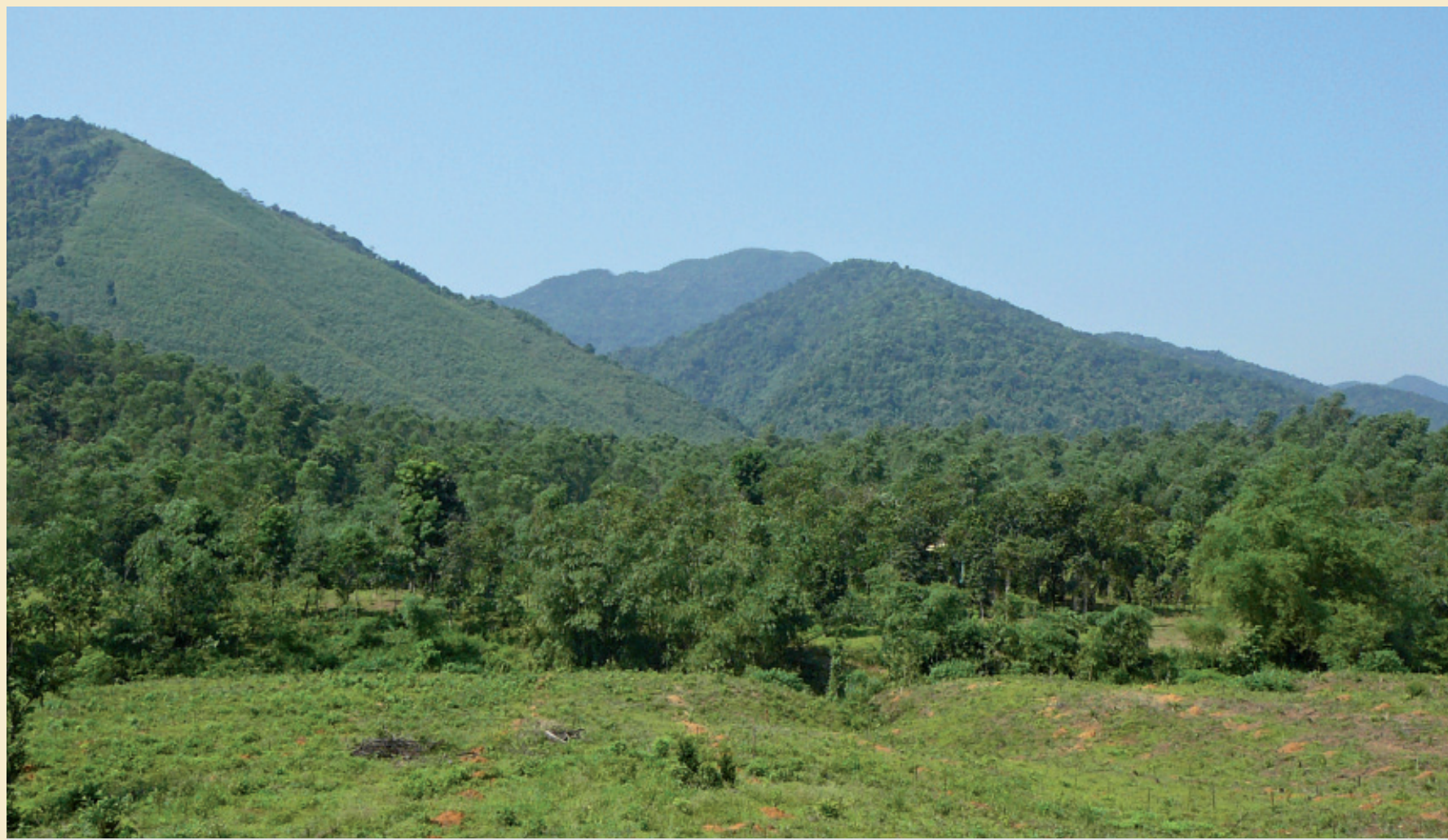

Photo 1.

Typical landscape at the border of Phong Dien Nature Reserve.

Photograph V. Verner. 


\section{RÉSUMÉ}

\section{UTILISATION DES PRODUITS FORESTIERS NON LIGNEUX DANS LA RÉSERVE NATURELLE DE PHONG DIEN AU VIETNAM : QUI LES COLLECTE, QUI LES CONSOMME, QUI LES VEND?}

Nous avons analysé dans cette étude la collecte et l'utilisation des produits forestiers non ligneux en zone rurale au centre du Vietnam. Il s'agit d'éléments importants pour mieux comprendre les interactions entre ménages et forêts dans les zones rurales proches de réserves naturelles, surtout dans les pays en développement à forte croissance économique. L'objectif de nos recherches était triple : (i) documenter les produits forestiers collectés dans la réserve naturelle et leurs utilisations, (ii) comprendre les facteurs pouvant motiver leur commercialisation, et (iii) connaître les attentes des familles locales quant aux capacités et à l'utilisation des ressources forestières. Les données ont été collectées au moyen d'entretiens semi-structurés entre 2008 et 2010 , auprès de familles installées dans ou aux alentours de la réserve naturelle de Phong Dien. Des entretiens ont été menés auprès de 48 familles représentatives des différentes conditions socio-économiques et naturelles dans la zone cible. Notre enquête montre que la plupart des produits forestiers collectés dans la réserve sont auto-consommés à des fins alimentaires, médicinales et de construction, et surtout selon une logique de subsistance. Cependant, certains végétaux faisant l'objet d'une forte demande, comme le rotin ou le licuala, sont récoltés en grandes quantités et commercialisés par le biais d’intermédiaires. Les familles ramassent également des produits forestiers pour satisfaire leurs besoins alimentaires en période de disette. Les deux stratégies peuvent contribuer à l'appauvrissement de la forêt, déjà avéré dans les perceptions des familles locales reflétant une raréfaction de la plupart des produits forestiers. Ces derniers sont collectés essentiellement par les familles ayant peu de terres cultivables, aux revenus peu diversifiés et pratiquant une agriculture dominée par les cultures annuelles. Il convient ainsi, pour toute nouvelle action de développement dans cette zone, d'envisager la mise en place de systèmes agricoles permettant de diversifier les revenus, couplée à des actions de sensibilisation des familles à l'importance de la biodiversité. Sans éliminer totalement l'extraction de produits forestiers, une telle approche permettrait de la maintenir à un niveau viable.

Mots-clés : produits forestiers, stratégie de subsistance, marchés, biodiversité, jardin familial, Vietnam.

\section{ABSTRACT}

\section{NON-TIMBER FOREST PRODUCTS UTILIZATION IN PHONG DIEN NATURE RESERVE, VIETNAM: WHO COLLECTS, WHO CONSUMES, WHO SELLS?}

In this study we have analysed collection and utilization of non-timber forest products in rural areas of central Vietnam. This is an important issue for better understanding of household-forest interactions in rural areas near natural reserves, particularly in developing countries with rapid economic growth. Our research aim was to (i) document forest products collected in the nature reserve and purposes of their use, (ii) understand driving forces for intended commercialization of those products, and (iii) document future expectation of local households on forest resources capacity and use. Data were collected via semi-structured interviews between 2008 and 2010 in households living in or close to Phong Dien Nature Reserve. Total number of 48 households, representing different socioeconomic and natural conditions of the target area, was interviewed. Our survey shows that the majority of the forest products in Phong Dien Nature Reserve were used as food, medicine or construction material, particularly at a subsistence level. Nevertheless, highly-demanded plant products, such as rattan or licuala palm, were gathered in bulk amount and commercialized via middlemen. Households collect forest products to supply the demand for food during the time of food shortages as well. Both strategies might lead to forest depletion, which was already documented via perceived decrease in occurrence of most forest products by local households. Collection of the forest products was maintained mainly by the households with limited farm size, lower income diversification and annual-cropsbased farming. Thus, alternative incomegenerating farming systems together with awareness of households about the importance of biodiversity should be considered in any further development activities in the area. That might not eliminate future collection of the forest products, but keep it at a sustainable level.

Keywords: forest products, livelihood strategy, markets, biodiversity, homegarden, Vietnam.

\section{USO DE PRODUCTOS FORESTALES NO MADEREROS EN LA RESERVA NATURAL DE PHONG DIEN EN VIETNAM: ¿QUIÉN LOS RECOLECTA, QUIÉN LOS CONSUME, QUIÉN LOS VENDE?}

En este estudio se analizó la recolección y utilización de productos forestales no madereros en áreas rurales del centro de Vietnam. Son elementos importantes para comprender mejor las interacciones entre hogares y bosques en áreas rurales cercanas a reservas naturales, especialmente en países en desarrollo con un rápido crecimiento económico. Nuestra investigación tenía un triple objetivo: 1) documentar los productos forestales recolectados en la reserva natural y sus usos, 2) comprender los factores que pueden motivar su comercialización y 3) conocer las expectativas de las familias locales en lo referente a la capacidad y uso de recursos forestales. Los datos se recopilaron entre 2008 y 2010 mediante entrevistas semiestructuradas a familias establecidas dentro o en los alrededores de la reserva natural de Phong Dien. Se realizaron 48 entrevistas a familias representativas de las diferentes condiciones socioeconómicas y naturales del área analizada. Nuestra encuesta muestra que la mayoría de productos forestales recolectados en la reserva se destinan al autoconsumo alimentario, medicinal y de construcción, especialmente desde una lógica de subsistencia. Sin embargo, algunos vegetales muy demandados, como ratán o licuala, se cosechan en grandes cantidades y se comercializan por medio de intermediarios. Las familias recolectan también productos forestales para satisfacer sus necesidades alimentarias en períodos de escasez. Ambas estrategias pueden contribuir al empobrecimiento del bosque, esto ya se comprueba en las percepciones de las familias locales que reflejan una reducción de la mayoría de productos forestales. Los productos forestales son recolectados principalmente por familias con pocas tierras cultivables, baja diversificación de ingresos y que practican una agricultura basada en cultivos anuales. Por ello, en cualquier nueva acción de desarrollo en esta zona, resulta conveniente prever el establecimiento de sistemas agrícolas que permitan diversificar los ingresos acompañados de acciones para sensibilizar a las familias a la importancia de la biodiversidad. Este enfoque, sin eliminar completamente la extracción de productos forestales, permitiría mantenerla en un nivel sostenible.

Palabras clave: productos forestales, estrategia de subsistencia, mercados, biodiversidad, huerto familiar, Vietnam. 


\section{Introduction}

In less developed regions, resource-poor households depend on a broad diversity of both plant- and animal-based non-timber forest products (NTFPs), either for consumption or commercial purposes, regardless whether they live close to or directly in the forest. Recent studies coincide on two main reasons influencing the collection of NTFPs. Firstly, the collection could be understood as a reaction of households to seasonal or unexpected natural or social hazards such as flooding, crop diseases, market failures, higher sickness rate of household members, political instability, food or cash insecurity (see e.g. Quang and Anh, 2006; Babulo et al., 2008; Heubach et al., 2011), while secondly the strategy might be considered as a regular activity continuously contributing to the household cash balance (Shackleton et al., 2007; Heubach et al., 2011; Saha and Sundriyal, 2012). According to Fu et al. (2009) or Saha and Sundriyal (2012), both strategies might lead to an unsustainable collection of NTFPs, which consequently could have a negative impact on the rural areas in terms of environmental degradation and biodiversity decline. Moreover, this could result in a lack of NTFPs supplies and a reduced standard of living among these specific rural households in the future.

This situation is common for south-eastern Asia countries, particularly Vietnam. During the last decades, Vietnamese economy has witnessed a stable and rapid economic growth that has brought many socioeconomic benefits to the population. However, it has also deepened inequality, particularly between rural and urban areas. Despite of constantly increasing urbanization, $68.3 \%$ of Vietnamese population is still situated mainly in rural areas and $48 \%$ of the overall Vietnamese households derive its livelihood from agriculture, which all-in-all sets an enormous pressure on a sustainable use of natural resources, such as forests. National efforts to protect these rich, but fragile, natural ecosystems resulted in the establishment of a number of protected areas. Nevertheless, the impacts of such strategies on forest-dependent households' livelihood have not yet been fully understood. Interestingly, apart from development studies (e.g. Boissière et al., 2006), scientific papers published on NTFPs collection in Vietnam are rather rare and deal particularly with human impact on plant diversity (Hoang et al., 2011), household socioeconomics (Mcelwee, 2008), forest policy (Nguyen, 2006), the collection of war residues as a by-product in the areas of central Vietnam (Boissière et al., 2011), and NTFPs commercialization (Quang and Anh, 2006). However, none of above mentioned studies analyse such issue in the Vietnamese protected areas. Therefore, our research aim was to (i) document forest products collected in the nature reserve and purposes of their use, (ii) understand driving forces for intended commercialization of those products, and (iii) document future expectation of local households on forest resources capacity and use.

\section{Methods}

\section{Study areas}

The research was conducted in the Phong My commune, a rural area about $50 \mathrm{~km}$ north-west of Hue city in the central Vietnam. Eastern part of study area is characterized by flat terrain situated approximately $50 \mathrm{~m}$ above sea level, which sharply rises at the east-west gradient towards the Annamite Mountains. The target area has a tropical monsoon climate with colder and humid rainy season (from late August till late January) and summer season that bring continental wind and hot, dry weather. The mean annual temperature fluctuates around $25^{\circ} \mathrm{C}$ and average annual relative humidity reaches 85 $88 \%$ (Villegas, 2004). The western part of the Phong My commune enters Phong Dien Nature Reserve (PDNR), which was established in order to protect local ecosystems against disturbances associated with rapid rural development (figure 1).

\section{Survey design}

The Phong My commune is the largest commune in the Phong Dien district with total area 394 square kilometres and is formed by ten villages. However, huge part of the commune area is part of the PDNR. To identify suitable households for our research, the following steps were made. Firstly we interviewed the representatives of the People Committee and individually all village heads to obtain an overview, how households utilize forest resources for their livelihood. Secondly, we raised a focus group discussion in each village with five randomly chosen household heads to both confirm and to extend information previously learned from the People Committee and village heads. Based on our new knowledge, we were able to identify four specific villages, where households regularly collect and utilise products from the forest.

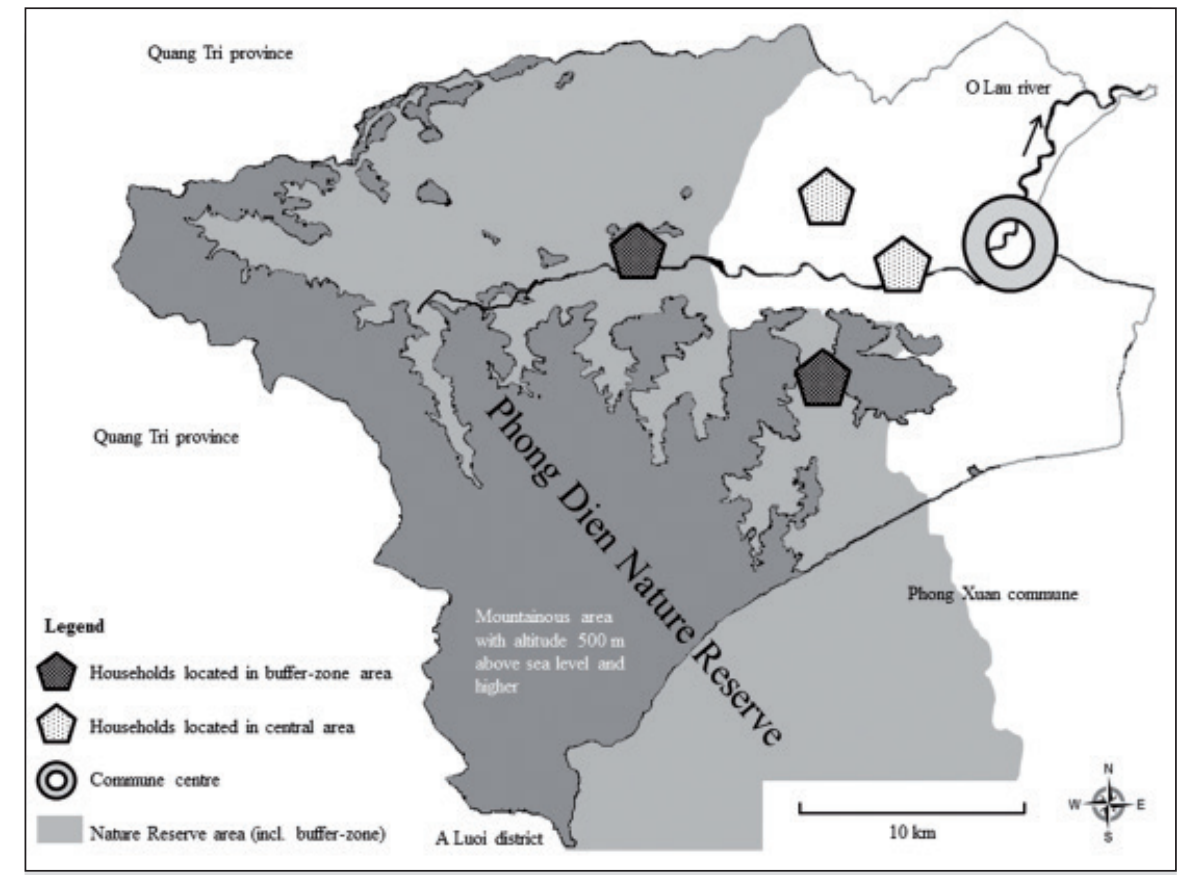

Figure 1.

Map of the study area. 


\section{Results}

\section{Livelihood strategies and socioeconomic characteristics of focused households}

Significant differences between the buffer-zone area and central area were documented particularly in terms of total farm size, total number of dependent members and number of household members involved in household activities (table I). No statistically significant difference in total value of per capita income between study areas was observed. Nevertheless, differences in the income diversification were documented, particularly in terms of annual crops, home gardening, government support and forest products. Besides the income, perception of possible threats that could affect NTFPs collection during the whole year was also documented. No significant difference between study areas was observed in the total amount of months of perceiving food security $(4.96,4.36$ months respectively, $p=0.531$ ), natural hazards, such as floods (2.27, 2.64 months, $p=0.667$ ) or involvement of household labour force in farm activities (2.92, 3.55 months, $p=0.300)$. Households in the buffer-zone area was more sensitive towards cash security $(5.35,3.32$ months, $p=0.067)$. On the other hand, they were more optimistic regarding the potential to use local water resources, especially O'Lau river, for fishing activities (3.19, 1.09 months, $p=0.088)$.

Table I.

Households and farm characteristics.

\section{Indicators}

\section{Farm size (ha)}

Household demographic indicators (in members) Household members Dependent members ( $\leq 14, \geq 60$ years)

Labour force (15-59 years)

Male labour force

Female labour force

Household members involved in off-farm activities

Household members involved in household-related activities

Household head age (years)

Household settled in study area (years)

Years of schooling (15+)

Per capita cash income (thousands VND)

Total cash income

Annual crops

Plantation

Home garden

Livestock

Fishing from local rivers

Small business

Salaries

Government

Forest products excluding timber (NTFPs)

Other

\section{$(\mathrm{N}=26)$ \\ Mean}

Buffer-zone area

SD

3.12

2.47
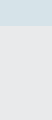

\begin{tabular}{|c|c|c|c|c|}
\hline 6.08 & 2.10 & 6.95 & 2.36 & 0.179 \\
\hline 1.58 & 1.27 & 2.36 & 1.43 & $0.050^{\star \star}$ \\
\hline 4.50 & 2.25 & 4.59 & 2.91 & 0.903 \\
\hline 2.23 & 1.50 & 2.23 & 1.66 & 0.994 \\
\hline 2.31 & 1.41 & 2.36 & 1.99 & 0.910 \\
\hline 1.19 & 1.96 & 0.82 & 1.05 & 0.427 \\
\hline 2.96 & 1.51 & 2.18 & 1.14 & $0.053^{*}$ \\
\hline 49.77 & 18.56 & 46.59 & 12.76 & 0.501 \\
\hline 19.88 & 11.90 & 24.32 & 12.64 & 0.218 \\
\hline 3.85 & 2.62 & 4.86 & 2.19 & 0.155 \\
\hline 3,106 & 1,898 & 2,563 & 1,990 & 0.391 \\
\hline 78 & 158 & 438 & 390 & $0.000^{\star \star \star}$ \\
\hline 904 & 1,424 & 763 & 1,514 & 0.742 \\
\hline 416 & 408 & 230 & 327 & $0.093^{*}$ \\
\hline 167 & 412 & 141 & 305 & 0.810 \\
\hline 41 & 166 & 8 & 36 & 0.358 \\
\hline 126 & 447 & 167 & 542 & 0.778 \\
\hline 291 & 635 & 213 & 327 & 0.605 \\
\hline 955 & 1,333 & 22 & 53 & $0.002^{\star \star *}$ \\
\hline 125 & 231 & 573 & 814 & $0.010^{* *}$ \\
\hline 4 & 14 & 9 & 15 & 0.266 \\
\hline
\end{tabular}

Note(s): *, **, and ${ }^{* * *}$ are significance at $90 \%, 95 \%$ and $99 \%$ respectively 1 US\$ 17,500 VND as of July 2009. 


\section{Collected non-timber forest products}

Based on our survey, 61 NTFPs regularly collected by local households were documented. Among them 39 plantbased and 22 animal-based products were identified (table II). From the total number of 39 plant-based NTFPs, the collection of 33 were documented in the buffer-zone area com- pared to 20 in the central area. In both study areas, plantbased forest products were used particularly as food $(46.2 \%)$, medicine $(14.5 \%)$, construction material (12.9\%), domestic tools (4.8\%), and firewood (1.6\%). Plant-based products, such as rattan, licuala palm and Vietnamese coriander, were the most frequently mentioned products being collected by local households. Maximum three pur-

Table II.

List of plant-based NTFPs collected in the study area.

\begin{tabular}{|c|c|c|c|}
\hline Product & Main uses & Purpose & Collector** \\
\hline Alocasia leaves & food & subsistence & D \\
\hline Agarwood & medicine & subsistence & M \\
\hline Bamboo & material & subsistence & $\mathrm{F}$ \\
\hline Bamboo shoots & food & both & $M, F, D$ \\
\hline Cardamom & food & subsistence & $\mathrm{F}$ \\
\hline Centella & food & subsistence & $\mathrm{D}$ \\
\hline Chinese box-orange & food & subsistence & $\mathrm{F}$ \\
\hline Chinese knotweed & food & subsistence & $\mathrm{F}$ \\
\hline Cogon grass & material & subsistence & F, D \\
\hline Colocasia corm & food, medicine & subsistence & $M, F$ \\
\hline Creeping woodsorrel & food & subsistence & $\mathrm{F}$ \\
\hline East Indian arrowroot & material & subsistence & M \\
\hline Fan-palm (leaves for thatching roofs) & material & subsistence & M, F, D \\
\hline Leaves of Fibraurera recisa & medicine & subsistence & M \\
\hline Firewood & firewood & both & $M, F, D$ \\
\hline Forest berries & food & subsistence & M \\
\hline Forest leaves & food & subsistence & $M, F, D$ \\
\hline Ganoderma mushroom & food & subsistence & D \\
\hline Giant elephant ear & food, medicine & subsistence & M \\
\hline Ginseng & food, medicine & subsistence & $\mathrm{M}, \mathrm{F}$ \\
\hline Graminoid used for making brooms & tools & both & $M, F, D$ \\
\hline Jackfruit & food & subsistence & $\mathrm{F}$ \\
\hline Leaves for making beverage (local name Lá bùm bạc) & food, medicine & subsistence & F, D \\
\hline Leaves of wild vegetable species (local name Rau ráo) & food, medicine & subsistence & $M, F, D$ \\
\hline Licuala palm (for making traditional conical hats) & tools & market & M, F, D \\
\hline Lotus & food, material & subsistence & $\mathrm{F}$ \\
\hline Malus sp. (local name Chi hải đường) & food & subsistence & $\mathrm{F}$ \\
\hline Mangosteens & food & subsistence & M \\
\hline Mushrooms with large “cap” & food & both & $M, F, D$ \\
\hline Pandans & food, medicine & both & M, F, D \\
\hline Rambutan & food & subsistence & M \\
\hline Rattan & tools & market & $M, F, D$ \\
\hline Leaves for salads (local name Rau éo) & food & subsistence & $\mathrm{M}, \mathrm{F}$ \\
\hline Taro & food & both & $M, F, D$ \\
\hline Tobacco & food, medicine & both & $\mathrm{M}, \mathrm{F}$ \\
\hline Tuber of wild vegetable (local name Củ bách bộ) & food, medicine & subsistence & $\mathrm{F}$ \\
\hline Vietnamese coriander & food & both & $\mathrm{F}, \mathrm{D}$ \\
\hline Wild fruit (local name Quả bipbip) & food & subsistence & M \\
\hline Yew & material & subsistence & M \\
\hline
\end{tabular}


Table III.

List of animal-based NTFPs collected in the study area.

\begin{tabular}{|c|c|c|}
\hline Product* & Purpose & Collector** \\
\hline Bee product - honey & both & $M, F, D$ \\
\hline Bee product - honeycomb & subsistence & $M, D$ \\
\hline Bee product - wax & market & M \\
\hline Bird - Pheasant & subsistence & M \\
\hline Civet & both & M \\
\hline Gecko & both & M \\
\hline Fish, mostly eel & both & M, D \\
\hline Local carnivores & subsistence & M \\
\hline Frog & both & M, D \\
\hline Java mouse deer & both & M, D \\
\hline Jungle fowl & both & M, D \\
\hline Local deer & market & $M, D$ \\
\hline Porcupine & both & $M, D$ \\
\hline Rattle snake & subsistence & M \\
\hline Small molluscs - snails, shellfish & both & M, F, D \\
\hline Small rodent - mouse & both & M \\
\hline Small rodent - bamboo rat & both & $M, D$ \\
\hline Snake - Python & market & $M$ \\
\hline Snake - Cobra & market & M \\
\hline Turtle & market & $M$ \\
\hline Water turtle & market & $M, F$ \\
\hline Wild boar & both & $M$ \\
\hline
\end{tabular}

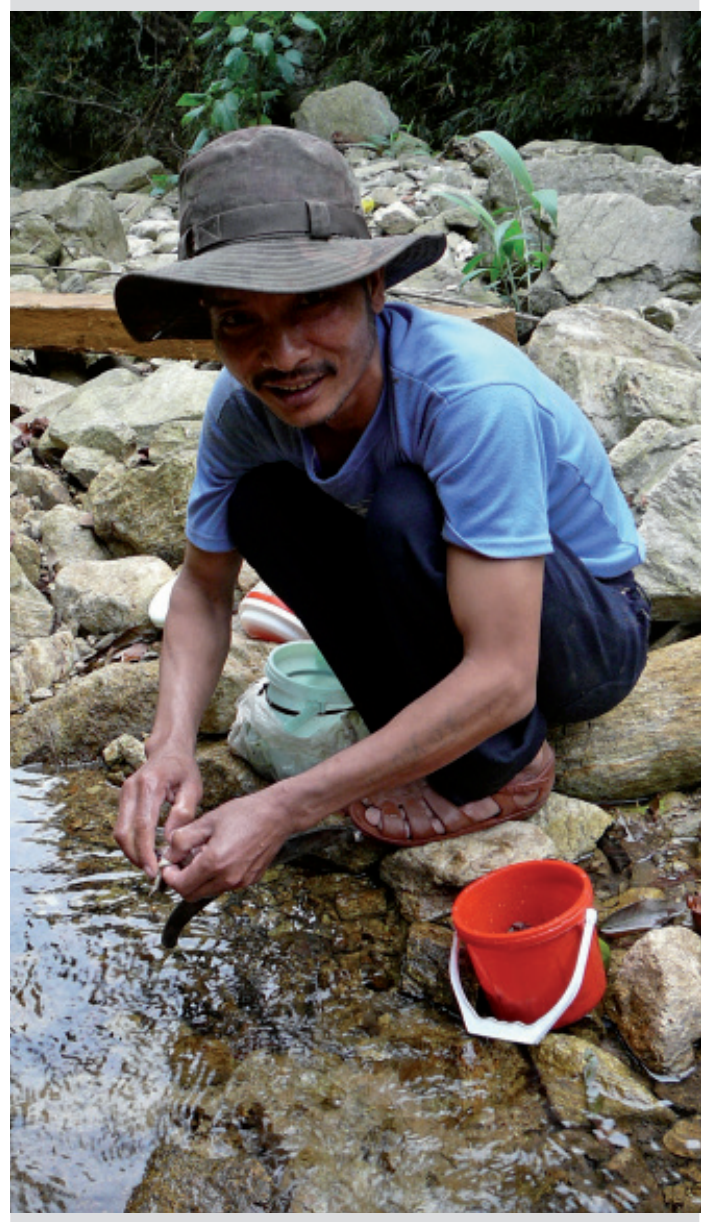

Photo 4

Local farmer of $\mathrm{Pa} \mathrm{Hi} \mathrm{language} \mathrm{group} \mathrm{is} \mathrm{collecting}$ small amphibians from the forest stream. Photograph V. Verner poses of use were reported for particular plant products. More than a half of plant-based NTFPs (51.3\%) had only one mode of use. Two and three different uses were reported for $38.5 \%$ and $10.3 \%$ of plant products, respectively. Typical examples of multipurpose products were bamboo, tobacco, ginseng, lotus or Colocasia corm. Most of the documented plant products (56.4\%) were collected all year round with only a few exceptions such as mushrooms or tobacco, which were collected seasonally. Distance to collection sites ranged from $500 \mathrm{~m}$ to $10 \mathrm{~km}$ and therefore, the collection of particular species was a time-consuming activity. According to our respondents, even two days are necessary to spent in the forest to collect a required amount of rattan, licuala palm or pandans. The quantity collected per one visit, however, differs according to particular product and ranges from $0.5 \mathrm{~kg}$ (mushrooms or edible fruits, such as pandans) to more than $300 \mathrm{~kg}$ (rattan stems).

Farmers' wives were more active in collection of $69.2 \%$, household heads in $61.5 \%$ and dependent members in $43.6 \%$ of all documented plant-based NTFPs. Furthermore, wives were exclusively involved in the collection of $23.1 \%$ plant-based products, i.e. bamboo, jackfruit and citruses, and wild fruits, such as Malus sp. or Chinese box-orange. Similarly, the same proportion of plant-based NTFPs (23.1\%), namely Colocasia corm, tree species used for construction poles, agarwood or Fibraurera recisa, was collected solely by household heads.

Furthermore, our survey identified 20 animal-based products regularly hunted/collected by farmers from the buffer-zone area, compared to eight in the central area (table III). One fifth of interviewed households (20.8\%) did not collect animal-based NTFPs as they were fully oriented on plantbased NTFPs only. Generally, frogs, gecko and snakes were the most collected products in both study areas. In bufferzone areas, civet, wild boar and porcupine were also mentioned by farmers as potential products, which could be sold on the local market or to the middlemen. The distance to collection and/or to hunting sites, ranged from one to seven kilometres or, expressed in time, from ten minutes to eight hours. Animal-based NTFPs were almost exclusively the domain of the household heads $(63.6 \%$ of identified products). Wives and dependent members were involved in the collection of only a few animal-based NTFPs, particularly honey, frogs, small rodents, molluscs and fish. 


\section{Commercialization of NTFPs}

The level of NTFPs commercialization varied among particular products. Solely for subsistence purposes served 27 out of 53 collected products in the buffer-zone area (50.9\%) and 18 out of 28 (64.3\%) in the central area (table IV). Plantbased products were commercialized on both local markets as well as via middlemen, particularly tobacco, taro, rattan and licuala palm. On the contrary, animal-based products were sold via middlemen only, instead of specific small animal species, which were sold on local markets as well. However, majority of products sold remain rather low in terms of total amount withdrawn from the local ecosystems. Two NTFPs represent an exception, i.e. rattan and licuala palm. Farmers were able to collect big amount of rattan per one visit in order to ensure a higher income as its purchasing price is quite low and fluctuates around 300 VND per one stem. Similarly, licuala palm were collected in quantities from 25 to $40 \mathrm{~kg}$ per one visit for expected price from 80 to 150 thousand VND per $30 \mathrm{~kg}$. Expected cash income earned from selling either rattan or licuala palm was equal to week salary in the rural areas of Vietnam. Based on our survey, $54.2 \%$ of households from the buffer-zone area were involved in collection of rattan, compared to $100 \%$ from the central area.

On the contrary, similar percentage of households involved in collecting licuala palm was documented at both study areas, $66.7 \%$ and $68.2 \%$ respectively. Altogether, the central area generates $22.34 \%$ of cash income from selling NTFPs compared to $4.02 \%$ in the buffer-zone area.

\section{Farmers' attitudes towards NTFPs collection and their perception of biodiversity dynamics}

We documented farmers' future expectations on using forest products and forest in general. Half of the interviewed households confirmed to reduce activities related to forest products collection in the future. The reasons for these intentions were particularly various health hazards, heavy work load and the continuous shift to new income-generating activities, such as plantation, home gardening or even to off-farm activities. Other reasons reported were the decreasing availability of forest products (47.4\%) and rising awareness on importance of forest resources conservation

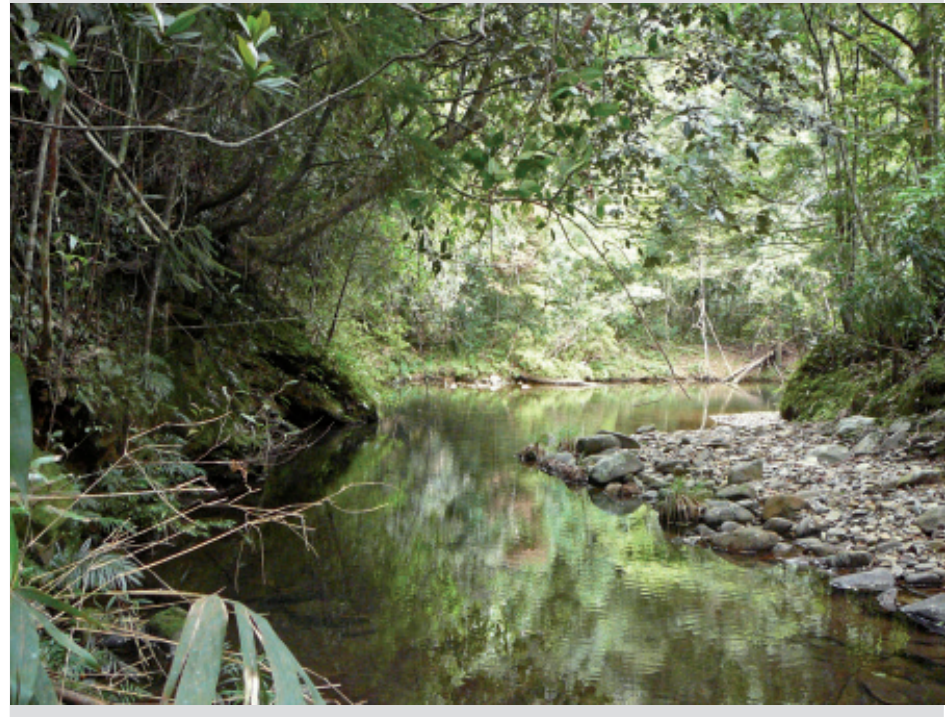

Photo 5

Example of forest ecosystem in Phong Dien Nature Reserve. Photograph Z. Polesny.

(43.2\%). Farmers reported also several risks related to NTFPs collection, including attacks of dangerous or venomous animals (e.g. tigers and snakes) or accidents caused by falling trees, explosions of war wrecks or slippery stones.

Additionally, farmers perceived occurrence decline of plant-based NTFPs (58.9\%), particularly tubers of wild vegetable, Colocasia corm, Chinese knotweed and Ginseng, and animal-based products (77.3\%), especially porcupine and rattle snake. Some farmers, however, stated that they always will use some forest resources in the future, particularly for food (Vietnamese traditional cuisine), ornamental purposes or for ritual purposes. When farmers were asked if they take their children to the forest to teach them about the nature, practically all responses were negative. However, almost all farmers $(90 \%)$ perceived the necessity of forest protection in their surroundings in order to preserve the forest and its ecosystem services for next generations. Farmers were aware of forest benefits for their livelihood, such as prevention of erosion and floods, supporting cash and/or food security. Correspondingly, they understood the importance of biodiversity conservation as it could have a positive effect on the potential development of agro-tourism in their villages.

Table IV.

Overview of quantity of collected forest products in both study areas.

\begin{tabular}{|c|c|c|c|c|c|c|c|c|}
\hline & \multicolumn{4}{|c|}{ Buffer-zone area $(\mathrm{N}=26)$} & \multicolumn{4}{|c|}{ Central area $(\mathrm{N}=22)$} \\
\hline Both plant-based and animal-based & 53 & 27 & 8 & 18 & 28 & 18 & 6 & 4 \\
\hline Animal-based & 20 & 3 & 6 & 11 & 8 & 3 & 3 & 2 \\
\hline
\end{tabular}

Note(s): Following symbols should be understood as follows, $\mathrm{S}$ - subsistence purposes, C - commercialization, $\mathrm{S}+\mathrm{C}$ indicates the combination of both. 


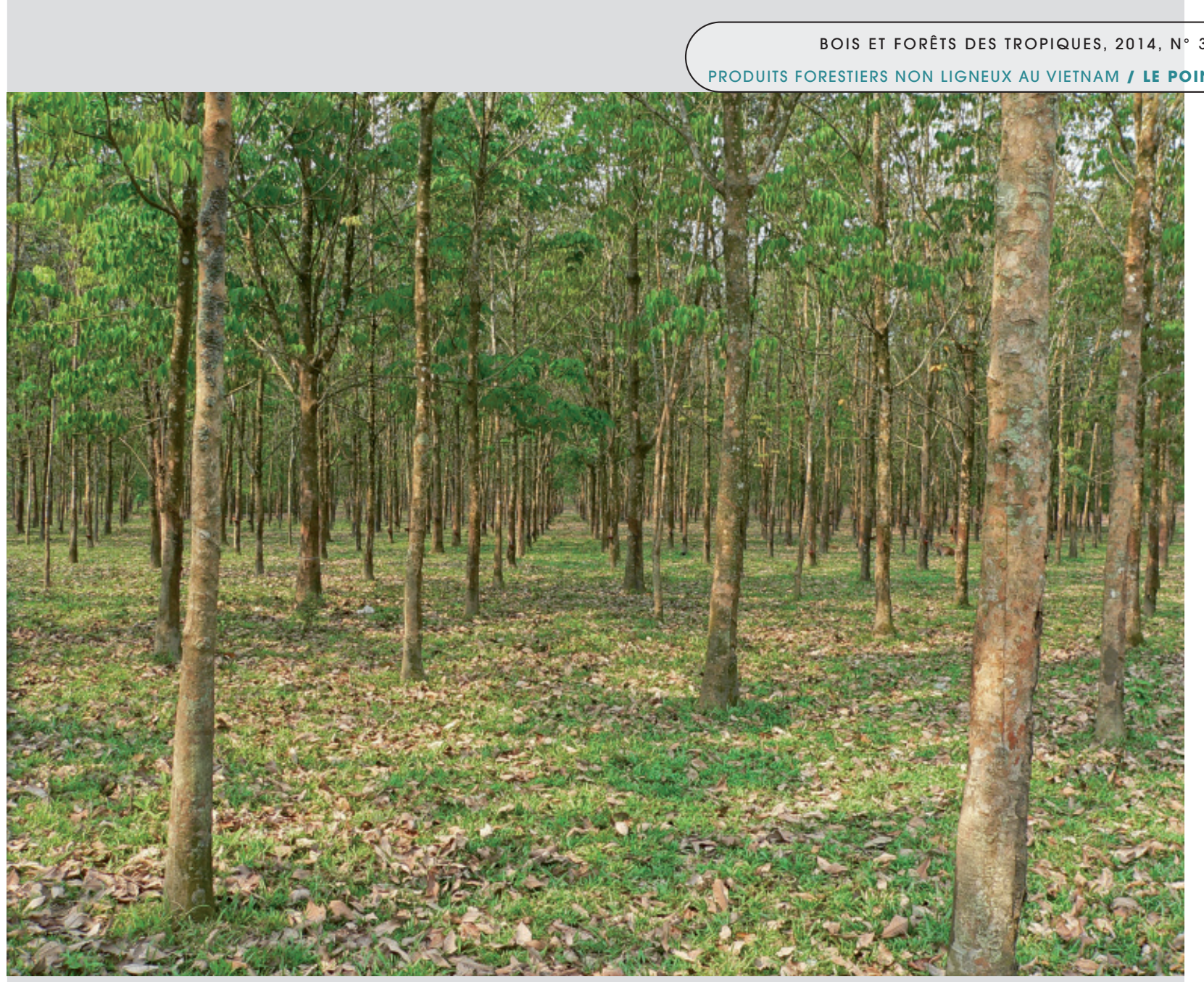

Photo 6

Rubber Hevea brasiliensis (Willd. ex A.Juss.) Müll.Arg. plantations play crucial role

from both economic and environmental perspective.

Photograph Z. Polesny

\section{Discussion}

We documented 61 products regularly collected as NTFPs by local households, which is higher number compare to other studies reported from Vietnam (Quang and Anh, 2006) or other tropical countries such as India (Saha and Sundriyal, 2012). Nevertheless, studies on NTFPs commercialization are not directly focused on detailed inventory of collected species, but rather on the ratio between subsistence and commercialization purposes of NTFPs for local households. Less than half of identified NTFPs (46\%) were intended solely for the market, which corresponds to other studies from eastern India (Mahapatra and Tewari, 2005) or Bangladesh (Kar and Jacobson, 2012). This could be explained through the lack of income diversification opportunities or land availability, which is continuously diminishing over time due to population pressure particularly in the central areas with larger households. The argument for this statement is that households from the buffer-zone area could also be considered as poor at the district level, but they generate significantly lower income from the forest collection, most probably due to larger farm size, higher government support and small-scale off-farm activities, such as fishing in local rivers (table I). Commercial collection of the forest products thus remain within the resource-poor households, particularly from the central area, as majority of interviewed households used for maintaining food security. These findings corresponds to other studies (Quang and Anh, 2006; Babulo et al., 2008; Davidar et al., 2008; Heubach et al., 2011).

NTFPs commercialization among targeted households was focused on a few species only, particularly those with prevailing constant demand, such as rattan (Peters et al., 2007) and was usually practiced by resource-poor households from central part of the commune, which had fewer opportunities to ensure adequate food security or to generate additional cash income. Contribution of selling NFTPs to household budget in target area was lower, $4.02 \%$ in buffer-zone area and $22.34 \%$ in central area, respectively, if we compare them with $39 \%$ reported from northern Benin (Heubach et al., 2011), 27\% from Tigray, northern Ethiopia (Babulo et al., 2008), 19-32\% from eastern India (Saha and Sundriyal, 2012), 31.5\% from southern China (Hogarth et al., 2013). Our values rather correspond with $15 \%$ observed in Malawi (Kamanga et al., 2009). The estimations of monetary value of extracted NTFPs in the present study were based on assumption that other commercialized NTFPs were sold at very low quantities, particularly in 
case of small animals, thus any attempts of calculation of economic value would be then less reliable (Mahapatra and Tewari, 2005). Majority of commercialized NTFPs in both study areas were sold via middleman, particularly animals. This is in contrast to other published studies where most of commercialized products were sold directly on local markets (Fedele et al., 2011; Saha and Sundriyal, 2012). Furthermore, our findings correspond with the study of (Wickramasinghe et al., 1996), who observed that commercial gathering is often dominated by men, whereas subsistence gathering represents regular task for all household members.

In order to understand the driving forces of the forest products collection in the target area, some difference between our two study areas have to be revealed as well. Due to the higher altitude, lack of favourable terrain and water resources, almost no rice is planted in the buffer-zone area. As a result, livelihood strategies are shifted particularly to running homegardens and food shortages are supplied through the collection of forest resources. Contrary to this, households in the central area are focused primarily on annual crops cultivation, mostly rice or peanuts, and livestock production. As farm size in the central villages is smaller compare to buffer-zone area, local households are forced to diversify their livelihood to off-farm activities. However, the resource-poor households fail in investment into small shop or restaurant and they turn their attention to forests. These findings are in opposite of other surveys (Davidar et al., 2008; Saha and Sundriyal, 2012), where better-off and educated households were more involved in NTFPs collection.

Correspondingly to other studies (Quang and Anh, 2006; Kamanga et al., 2009; Saha and Sundriyal, 2012) we observed that the household location and the location of collection places should be considered as crucial indicators influencing forest products collection as well. Our respondents had to walk up to eight kilometres deep into the forest to reach collection sites, which is however about half distance compare to other studies, but it explains in a certain manner the structure and level of commercialization of the collected NTFPs. Households located in the buffer-zone area were quite remote from market places and the only way how to sell the forest products is to use 0 Lau river. Thus, only rattan, bamboo and similar plant species used as a construction material are suitable for such kind of transportation.

Based on our data, farmers themselves claimed that the level of biodiversity is decreasing for majority of both plant and animal products that they collect in our study areas. Some papers reveal (Babulo et al., 2008; Vlkova et al., 2011) that successful adoption of homegardens or perennial cropping system by local households could be perceived as a suitable and desirable strategy in order to reduce the forest products collection. Nevertheless, we have to consider the statement of almost fifty percentages of targeted households about the future forest products utilisation. The reasons for that attitude were quite acceptable and reasonable, such as collection of specific plant species for traditional culinary or cultural purposes. On the other hand, income diversification example from buffer-zone area indicates certain viability of promoting the adoption of new farming systems as well as the awareness of the farmers about the role of biodiversity for development of rural areas close to or in the Phong Dien Nature Reserve.

\section{Conclusion}

Our survey identified that the majority of NTFPs in Phong Dien Nature Reserve were used as food, medicine or construction material, particularly at a subsistence level. Nevertheless, resource-poor households, who were less successful to generate additional income from off-farm activities or diversification of farm production, collected quite large quantities of specific forest products with a promising market demand, such as rattan or licuala palm. Nevertheless, alternative farming systems could be recognized as a suitable tool to reduce the collection of commercial-oriented forest products in the target area. It is therefore necessary that these systems need to become attractive for the households with limited access to land resources and with higher number of dependent members. Thus, homegardens and other farming systems based on perennial crops seem to be a promising strategy in that way. Nevertheless, the majority of households living near or in the forest claimed that they will always use forest products at least as subsistence for culinary and cultural purposes. On the other hand, households in the study areas perceive that the occurrence of both plant and animal forest products decrease significantly during the last decade. However, the awareness of households about the positive impact of biodiversity conservation on rural development through e.g. ecosystem services or agro-tourism is increasing. These off-farm benefits might never eliminate the collection of NTFPs in the target area, but they have the potential to keep that activity at a sustainable level.

\section{Acknowledgement}

Research was financially supported by the ODA project financed by Ministry of Agriculture of the Czech Republic number MZe/B/8 and by the Internal grant agency of Faculty of Tropical AgriSciences number 20145025. The authors gratefully thank the anonymous referees for their valuable comments. 


\section{References}

ANGELSEN A., WUNDER S., 2003. Exploring the forest-poverty link: key concepts, issues and research implications. Bogor, Indonesia, CIFOR, 58 p.

BABULO B., MUYS B., NEGA F., TOLLENS E., NYSSEN J., DECKERS J., MATHIJS E., 2008. Household livelihood strategies and forest dependence in the highlands of Tigray, Northern Ethiopia. Agricultural Systems, 98 (2): 147-155.

BOISSIERE M., BASUKI I., KOPONEN P., WAN M., SHEIL D., 2006. Biodiversity and local perceptions on the edge of a conservation area, Khe Tran Village, Vietnam. Inti Prima Karya, Jakarta, Center for International Forestry Research (CIFOR), 106 p.

BOISSIÈRE M., SHEIL D., BASUKI I., 2011. A booming trade?: how collection of war residues affects livelihoods and forest in Vietnam. International Forestry Review, 13 (4): 404-415.

DAVIDAR P., ARJUNAN M., PUYRAVAUD J. P., 2008. Why do local households harvest forest products? A case study from the southern Western Ghats, India. Biological Conservation, 141 (7): 1876-1884.

FEDELE G., URECH Z. L., REHNUS M., SORG J. P., 2011. Impact of women's harvest practices on Pandanus guillaumetii in Madagascar's lowland rainforests. Economic Botany, 65 (2): 158-168.

FU Y. N., CHEN J., GUO H. J., CHEN A. G., CUI J. Y., HU H. B., 2009. The role of non-timber forest products during agroecosystem shift in Xishuangbanna, southwestern China. Forest Policy and Economics, 11 (1): 18-25.

HEUBACH K., WITTIG R., NUPPENAU E. A., HAHN K., 2011. The economic importance of non-timber forest products (NTFPs) for livelihood maintenance of rural west African communities: A case study from northern Benin. Ecological Economics, 70 (11): 1991-2001.

HOANG V. S., BAAS P., KESSLER P. J. A., SLIK J. W. F., TER STEEGE H., RAES N., 2011. Human and environmental influences on plant diversity and composition in Ben En National Park, Vietnam. Journal of Tropical Forest Science, 23 (3): 328-337.

HOGARTH N. J., BELCHER B., CAMPBELL B., STACEY N., 2013. The role of forest-related income in household economies and rural livelihoods in the border-region of southern China. World Development, 43: 111-123.

KAMANGA P., VEDELD P., SJAASTAD E., 2009. Forest incomes and rural livelihoods in Chiradzulu District, Malawi. Ecological Economics, 68 (3): 613-624.

KAR S. P., JACOBSON M. G., 2012. NTFP income contribution to household economy and related socio-economic factors: Lessons from Bangladesh. Forest Policy and Economics, 14 (1): 136-142.

MAHAPATRA A. K., TEWARI D. D., 2005. Importance of nontimber forest products in the economic valuation of dry deciduous forests of India. Forest Policy and Economics, 7 (3): 455-467.

MCELWEE P. D., 2008. Forest environmental income in Vietnam: household socioeconomic factors influencing forest use. Environmental Conservation, 35 (2): 147-159.
NGUYEN T. Q., 2006. Forest devolution in Vietnam: Differentiation in benefits from forest among local households. Forest Policy and Economics, 8 (4): 409-420.

PETERS C. M., HENDERSON A., MAUNG U. M., LWIN U. S., OHN U. T. M., LWIN U. K., SHAUNG U. T., 2007. The rattan trade of Northern Myanmar: Species, supplies, and sustainability. Economic Botany, 61 (1): 3-13.

QUANG D. V., ANH T. N., 2006. Commercial collection of NTFPs and households living in or near the forests: Case study. In: Que, Con Cuong and Ma, Tuong Duong, Nghe An, Vietnam. Ecological Economics, 60 (1): 65-74.

REYES-GARCIA V., HUANCA T., VADEZ V., LEONARD W., WILKIE D., 2006. Cultural, practical, and economic value of wild plants: A quantitative study in the Bolivian Amazon. Economic Botany, 60 (1): 62-74.

SAHA D., SUNDRIYAL R. C., 2012. Utilization of non-timber forest products in humid tropics: Implications for management and livelihood. Forest Policy and Economics, 14 (1): 28-40.

SHACKLETON C. M., SHACKLETON S. E., BUITEN E., BIRD N., 2007. The importance of dry woodlands and forests in rural livelihoods and poverty alleviation in South Africa. Forest Policy and Economics, 9 (5): 558-577.

VILLEGAS P., 2004. Flood modelling in Perfume River basin, Hue Province, Vietnam. Thesis, International Institute for Geo-Information Science and Earth Observation, Enschede, The Netherlands, $86 \mathrm{p}$.

VLKOVA M., POLESNY Z., VERNER V., BANOUT J., DVORAK M., HAVLIK J., LOJKA B., EHL P., KRAUSOVA J., 2011. Ethnobotanical knowledge and agrobiodiversity in subsistence farming: case study of home gardens in Phong My commune, central Vietnam. Genetic Resources and Crop Evolution, 58 (5): 629-644.

WICKRAMASINGHE A., PEREZ M. R., BLOCKHUS J. M., 1996. Nontimber forest product gathering in ritigala forest (Sri Lanka): Household strategies and community differentiation. Human Ecology, 24 (4): 493-519. 